\title{
INDRUKKE VAN DIE AMERIKAANSE KLEURBELEID IN VERGELYKING MET ONS BELEID VAN APARTHEID.
}

\begin{abstract}
Die Afrikaner is self skuldig as hy in die buiteland misverstaan en dikwels misdui word ten opsigte van sy beleid van apartheid as opiossing van die kleurvraagstuk in sy eie gebied. Dit is die gevolg van ons druk geskryf in die pers, in tydskrifte en van ons politieke toesprake, waardeur ons gedagtes en woorde kwytraak wat dikwels nie pas binne die nog steeds wordende beleid van apartheid nie. Ons stel dit so asof die beleid van apartheid volkome uitgewerk is, asof ons al volkome duidelikheid verkry het ontrent al die implikasies van hierdie beleid, asof alle Afrikaners al ooreenstem omtrent hierdie beleid. Ek het eenkeer hoor sê in verband met die voorgenome wetgewing van wyle genl. Hertzog insake die naturellevraagstuk dat dit onduidelik sal bly vir elkeen wat dit lees totdat die leser besluit dat die hele stuk onduidelik moet wees-dan verstaan hy dit. Dit is geen aanmerking wat tekort doen aan daardie stuk wetgewing nie, maar wel 'n waardering. As alles nog nie omlyn kan word nie, sal dit tog sinneloos wees om bakens op te stel, grense te trek, die sisteem dig te sluit-en dan te handel asof daar geen verdere lig oor die saak aangeneem en opgeneem sal word nie. Ek vrees ons het sinds daardie wetgewing nog nie veel verder gevorder nie, behalwe dat ons duidelikheid verkry het oor sekere onderdele. Maar waar 'n mens wel teen beswaar het, is dat skrywers en sprekers aan die wêreld die indruk gee asof ons gereed is om 'n afgeronde skema nou punt vir punt uit te voer. Welke verantwoordelike politikus sal vandag wil begeer dat ons klaar is met ons beleid van apartheid? Dit is 'n kultuurtaak wat nog steeds groeiend is. Hoe janlmer dan dat ons dit 'n politieke strydpunt laat word het. Vir 'n oomblik mag dit wel die gemoedere streel, mag dit 'n verkiesing se uitslag bepaal - maar die voordeel is kortstondig en bring ons in internasionale kalklig. Nie dat ons bang hoef te wees vir hierdie soeklig nie, maar laat ons die geleentheid gee aan sodanige kritici om ons reg te beoordeel. Vandag geskied dit bywyse van 'n bevooroordeelde propaganda, van 'n pers en nuusburo wat enigiets aangryp om hierdie beleid in verkeerde lig te plaas. Laat ons skrywers versigtig wees in wat hulle skrywe. Ons is nie almal politici nie en is nie almal presies op hoogte van al die fynere punte van die beleid van apartheid nie. Laat ons dan nie voorgee dat ons
\end{abstract}


wel goed op hoogte is nie, om dan te vind dat die heftigste kritiek juis op die swakste punt gemik is nie.

Ek waag om hierdie gedagte te onderstreep want dit was juis my cerste indruk met ons besoek in Amerika dat ons tydskrifte wel daar gelees word en dat gretiglik gegryp word na enige nuus oor ons kleurbeleid. Korrespondente van Amerikaanse blaaie in ons land moet dubbel versigtig wees. As dieselfde woorde en dieselfde gedagtes oor apartheid in een van ons binnelandse blaaie geskryf is, dan word dit gelees deur ons eie mense wat dieselfde kultuuragtergrond het as die skrywer. Ons verstaan by aanvoeling en meevoeling sy gedagtes, sonder dat hy pynlik omskrywend hoef te wees. Maar ons moet onthou dat die Amerikaner nie bekend is met ons agtergrond nie en dat die mees eenvoudige sin op hulle 'n wanindruk maak, die indruk van onderdrukking gee, die skerpste kritiek ontlok. As sulke terme soos "baasskap van die Afrikaner," "voogdyskap," „lokasie,” „gelykstelling," ,handhawing van blanke bestaan" gebruik word, moet hulle versigtiglik omskrywe word. Ek sê dit uit eie suur ervaring. Nadat ek die interpretasie van hierdie terme aangehoor het en die betekenis wat daaraan geheg is verneem het, het ek geskrik by die gedagte dat onsself die skuld dra vir al die wanindrukke, al die verkeerde propaganda, die agitators wat ons eie goedbedoelde woorde kwoteer en ons voor die wêreldregbank as fasciste, onderdrukkers en slawedrywers laat paradeer.

Hoe kan hierdie fout nou herstel word? Deur nog te skrywe en nog te praat? Dan kan ons ons eie lof der sotheid sing. Die enigste weg is om op te hou met skrywe en op te hou met praat. Die kritici sal wel probeer om die wêreld op hoogte te hou maar as daar van positiewe kant slegs met goedgesinde aksie voortgegaan word, sal die wêreld spoedigr oortuig word van welwilelndheid teenoor die gekleurde deel van ons samelewing.

Ons welwillendheid is tog aanwesig en veral in die afgelope twintig jaar is daar gew'eldig vordering gemaak in die verkryging van 'n billike en regverdige verhouding. Ek kan maar één saak noem: ons geskryf oor apartheid is oneindig veel kouer, meer gevoelloos en hard, as wat ons persoonlike verhouding teenoor die naturelle en kleurlinge is. Ons behandel daardie mense in die gees van: God het hulle langs ons en by ons gestel in hierdie land en hulle welsyn is ook ons welsyn. Ons sien hulle graag vorder, is dankbaar as daar werksaamheid, verantwoordelikheid, cerlikheid, vooruitstrewendheid by hulle openbaar word en ons bevorder dit ook. Hoe sal en kan ons dan al ons private en publieke toegeneentheid verklaar, as ons gesondheidsklinicke, sosiale werkers, sending, 
verbeteringshuise, skole, hospitale, behuisingskemas, saniteit, opvoeding van volwassenes, private wonings, malariabestryding ens. ens. in ag neem? Ja, inderdaad, ons doen veelmeer as wat ons sê-ons optrede is veelmeer vaderlik as die veelbesproke voogdyskap. Ons laat nie toe dat ons naturelle uitgebuit word deur parasiete in ons samelewing nie. Ons tree op vir hulle en in hulle belang. Ons hele optrede word beheers deur die Boere-motief, dat die naturelle kinders is wat geleer en beskerm moet word totdat hulle ontwikkel het tot daardie selistandigheid dat hulle hulself en daardeur hul eie mense kan bedien.

Maar dit weet die buitelander nie en dit is juis wat hy moet weet. Maar nou moet hy uit begrippe wat by ons welbekend is en by hulle onbekend, ons beoordcel. Dit geskied op die V.V.O. en daarom voel ons so seer en ag dit as beswaddering van ons goeie naam as persone en landjies wat die balk in eie oog het die splinter uit 'n ander se oog wil haal.

Nou wil ek eers 'n paar indrukke weergee van die kleurverhouding soos ek dit met 'n oop oog en oor verneem het in die Noordelike State van die V.S.A. Hierop moet besonder gelet word, die Noordelike State, want die kleurprobleem in die Suidelike State word heeltemal anders gesien en daar word in die pers van Amerika telkens nog skerp kritiek uitgeoefen op die suidelike deel.

$\mathrm{Na}$ my eie mening is daar geen beleid in Amerika wat betref die rasseverhoudings nie. In hierdie land tref ons die groot verskil aan met ons: ons skrywe is koud en hard, terwyl ons doen simpatiek en welwillend is; hulle skrywe is simpatiek en welwillend, terwyl hulle doen en late tamelik onverskillig en traak-my-nie-agtig is. Voor die wêreld word geposeer met 'n liberale beleid van gelykstelling, maar daar is hoegenaamd geen sprake van in die praktyk nie. Ek het daar weggegaan met die gedagte dat daar tussen die Amerikaanse en Suid-Afrikaanse houding ten opsigte van die gekleurde rasse nie die minste verskil bestaan nie. Ek wil graag hierdie bewering staaf.

Dit is wel waar dat die neger in dieselfde werkkringe staan, dieselfde lone verdien, in dieselfde waens per trein ry, aan dieselfde tafels in die cetsalon eet, langs blankes sit en gesels. Skynbaar is dit dan heeltemal in teëspraak met my bewering. Maar hoe verklaar $U$ dat hulle aparte woonbuurte het in New York, in Grand Rapids, in Chicago? Ons noem hierdie aparte woonbuurtes lokasies, maar dit is al wesenlike verskil. Toe ons in Grand Rapids was, het een neger 'n huis wou koop in 'n blanke buurt en dadelik was die hele buurt in opstand-en die koop het nie deurgegaan nic. In Chicago het daar 'n insypeling plaasgevind in die blanke woonbuurt, waar daar 'n gemeente was van die Christian 
Reformed Church, met 'n mooi kerk. Die blankes het daar weggetrek, na Berwyn gegaan, moes 'n nuwe kerk bou. Maar, spreek hierdie dinge dan nie duidelike taal nie?

Ek het nie geweet waar die negers in Grand Rapids woon nie en is per motor deur hierdie woonbuurt gebring, sonder waarskuwing dat ons nou na die negerbuurt gaan. Hierdie buurt lê nie afgeskei van die blankes se wonings af, soos ons dit hier verkies nie. Maar ons was skaars daarbinne en sonder dat een enkele neger opgemerk is, toe ek die opmerking maak dat hier seker nie blankes woon nie. Die buurt het dieselfde tipes van huise, maar met die verskil dat die onnetheid jou aandag trek. Die huise is verwaarloos en vuil en die hele buurt dra dieselfde opmerklike tekens.

Hierdie selfde aparte woonbuurte het ons in Denver aangetref. Wat sê ons mense in Amerika van hierdie vorm van apartheid?

Ek het in baie huise van blankes gekom gedurende ons verblyf. In nie een het ek 'n neger aangetref nie en in gesprekke het dit duidelik geword dat daar dus ook sosiale apartheid bestaan. Slegs één ouerpaar het nie beginselbeswaar gehad dat hul kinders mag trou met negers nie, maar al die ander wat daaroor gespreek is, het beweer dat dit ondenkbaar is.

Dit was vir my opvallend dat die Chr. Ref. Church, wat so besonder aktief is op sendinggebied, wat sendingarbeiders uitstuur na China, Ceylon, Nigerië (en hier onder swartmense) en na die Indiane in hul eie land, nie ' $n$ enkele arbeider het onder die negers in hul eie land nie. Immers, dit kan heel maklik in Grand Rapids self gedoen word, hier waar hul skole staan en hul sentrum is. Ek moet vermeld dat daar 'n twintigtal negers op Calvin College is. Maar aan sending onder die negers van Grand Rapids word niks gedoen nie. Ek het navraag gedoen-en wat was die antwoord? Wat sal ons met hulle maak as hulle die Gereformeerde leer omhels-ons kan hulle tog nie in die blanke kerke inneem nie. As dit gedoen sou word, dan sou die blankes weer by die kerkdeur uitgaan. Dit sal waar wees, gesien die gebeurde in Chicago. Wat dink ons van hierdie vorm van apartheid?

Ten slotte: 56 jaar lank word noual sendingwerk gedoen onder die Rooihuide, onder die Zuni en Navahoe stamme. Nog altyd word die Evangelie deur middel van Engels aan hulle gebring. Nog nooit het ons geesverwante in die moedertaal van die Indiaan gepraat nie: hulle beweer dat dit te moeilik is om aan te leer. Die Afrikaner kan miskien hier ' $n$ voorbeeld wees-ons wat juis beskuldig word dat ons 'n Herrn-volk moraal het-ons bedien ons van die taal wat spreek na die hart, die moedertaal van die stam waar ons werk. 
Juis met ons besoek aan die sendingveld het daar die eerste sendinghelper, Indiaan van geboorte, met sy vrou gekom: George Henry. Albei is deur die Reformed Bible Institute opgelei en het hulle taak begin. Ek het gevra waarom hulle hom nou nie bevestig as predikant in die midde van sy volk nie. Maar daar is besware, gewigtige besware. Ek gee die beswaar in sy Engels weer, soos dit aan my gegee is: "Then he would be eligible to a call in any Christian Reformed Church." Sien U, dit mag nie. Hy mag nie vir blankes predikant wees nie. Tot die stigting van 'n eie kerk vir die Indiane kom dit ook nie. En wat van hierdie vorm van apartheid?

Geen beleid word neergeskryf nie-maar 'n beleid is daar. Ek kan alleen praat van ons geesgenote se houding in Amerika. Maar dit was vir my duidelik: daar is geen wesensverskil nie. Miskien 'n graadsverskil: getemperde apartheid teenoor duidelike apartheid as beleid.

Daar is egter daardie wesenlike verskille tussen die twee lande en hulle gekleurde rasse. Dikwels is al daarop gewys dat die getalle vir die Amerikaner geen bedreiging is nie. Miskien het ons teveel probeer bewys deur statistieke. Die wesensverskil is nie getalle nie, maar wel beskawingspeil en stamverwantskap. Die beskawingspeil van die Amerikaanse neger is baie hoër as die van ons Afrikaanse naturel. 'n Mens het vrymoedigheid om met hom te praat.

Maar ook die beskawingspeil word bereik, word verkry. Vir my is die belangrike dat die Neger in Amerika 'n enkeling, 'n individu is. Daar is geen negerstamme met eie taal, tradisie, kultuur nie. Hulle praat Amerikaans. Hierdie saak moet in die buiteland veelmeer beklemtoon word. Ons beleid van apartheid word slegs voorgestel as 'n beleid van blanke selfbehoud, terwyl dit ook 'n beleid is van die behoud van die Godgegewe reg van 'n eie taal, eie tradisie, eie kultuur. Die wêreld sal armer wees as die stamtale van ons naturelle sou uitsterf en wegskeuring uit hul tradisie sal verwildering teweegbring. As ons in Suid-Afrika die Amerikaanse individualistiese politiek sou nastreef-_dan sou ons voor die wêreldregbank moes kom onder beskuldiging van geestelike moord. Niemand mag 'n Godgegewe erfenis vervreem nie.

Hierdie saak van apartheid het dus sy positiewe kant en nie slegs 'n negatiewe, soos so dikwels in geskrifte beweer word nie. Die Liberalistiese beleid van gelykstelling is juis intens negatief. Europeaniseer die naturel, ruk hom uit sy stam, laat hom sy nasietrots inboet-dit is die beleid. As enigiemand dit in Amerika as beleidspunt stel: breek die nasietrots af, sou hy sekerlik tronkstraf moet uitdien, of op die elektriese stoel te lande kom, vanweë niks minder as hoogverraad nie.

Potchefstroom.

S. P. VAN DER WALT. 